Jurnal Care Vol .5, No2,Tahun 2017

\title{
PERSEPSI PEMENUHAN KEBUTUHAN NUTRISI PADA PASIEN DIABETES MELLITUS DI DESA SAWAH KUWUNG KARANG ANYAR
}

\author{
Endah Sri Wahyuni ${ }^{1)}$, Hermawati $^{2}$ \\ ${ }^{1,2)}$ STIKES ‘Aisyiyah Surakarta \\ email: esw_ns@yahoo.com
}

\begin{abstract}
Diabetes Mellitus (DM) is a case with the increasing patients number almost every year. One of the supporting factors that can stabilize the blood sugar is DM management known as the four main pillars standing for education, diet, physical exercise and pharmacological management. The study purpose is to determine the perception of the nutritional needs fulfillment in Diabetes Mellitus patients. Research methods; Qualitative method with phenomenology approach with purposive sampling method. Population in this research is patient of Diabetes Mellitus in region "Surub Tani". Samples in qualitative research are also called participants. This study used 8 participants. The results showed that the management of nutritional diets in DM patients will be successful if the patient has good adherence in the diet, for that $D M$ patients need good motivation. The results showed that the nutritional diets management in DM patients will be successful if the patient has a good devotion on running the diet, therefore good motivation will help DM patients to keep running on their diet program. Motivation will turn out well if the DM patients get high support from their family and also access for a good health care. Respondents who have good family support then have good adherence while respondents who have poor family support then have no compliance. The conclusion after the research will be like respondents who have good family support and devotion while in the other side respondents who have poor family support then do not have any conformation.
\end{abstract}

Keywords: Diabetes Mellitus, Nutritional Fulfillment, Perception

\begin{abstract}
ABSTRAK
Diabetes Mellitus (DM) merupakan kejadian dengan jumlah penderita semakin meningkat tiap tahunnya. Salah satu faktor pendukung yang dapat menstabilkan gula darah adalah penatalaksanaan DM yang dikenal dengan empat pilar utama meliputi edukasi, diet, latihan jasmani dan pengelolaan farmakologis. Tujuan penelitian untuk mengetahui persepsi pemenuhan kebutuhan nutrisi pada penderita Diabetes Mellitus. Metode Penelitian; metode kualitatif dengan pendekatan fenomenologi dengan metode pengambilan sampel purposive sampling. Populasi dalam penelitian ini adalah penderita Diabetes Mellitus di wilayah Suruh Tani. Sampel pada penelitian kualitatif disebut juga partisipan. Penelitian ini menggunakan 8 partisipan. Hasil Penelitian menunjukkan bahwa pengelolaan diet nutrisi pada pasien DM tersebut akan berhasil apabila penderita memiliki kepatuhan yang baik
\end{abstract}


dalam menjalankan diet, untuk itu penderita DM membutuhkan motivasi yang baik. Motivasi akan berkembang dengan baik apabila seorang penderita DM mendapatkan dukungan keluarga dan akses pelayanan kesehatan yang baik. Responden yang memiliki dukungan keluarga yang baik maka memiliki kepatuhan yang baik sedangkan responden yang mendapat dukungan keluarga yang kurang baik maka tidak memiliki kepatuhan.

Kata Kunci : Diabetes Mellitus, Pemenuhan Nutrisi, Persepsi

\section{PENDAHULUAN}

Diabetes Mellitus (DM) merupakan kejadian dengan jumlah penderita semakin meningkat tiap tahunnya. DM merupakan penyakit dengan kadar glukosa darah yang melebihi normal, yakni kadar gula darah sewaktu sama atau lebih dari $200 \mathrm{mg} / \mathrm{dl}$ dan kadar gula darah puasa $126 \mathrm{mg} / \mathrm{dl}$ (Guyton \& Hall, 2008). DM ini merupakan sekelompok kelainan dari heterogen yang ditandai oleh kenaikan kadar glokusa dalam darah atau hiperglikemia (Smeltzer, 2008). Salah satu faktor pendukung menstabilkan gula darah adalah adanya pengetahuan yang baik mengenai diet Diabetes Mellitus.

Diabetes melitus memiliki dampak yang serius pada pasien dan keluarga pasien. Dampak lain yang timbul adalah perubahan peran pada keluarga, gangguan psikologis, masalah ekonomi, perubahan kebiasaan sosial, produktivitas dan perubahan gaya hidup (Lewis et al, 2011). Pengelolaan yang baik dalam penatalaksanaan DM akan meningkatkan kualitas hidup pasien DM menurut konsensus PERKENI (Perkumpulan Endokrinologi Indonesia, 2011). Penatalaksanaan DM dikenal dengan empat pilar utama meliputi edukasi, diet, latihan jasmani dan pengelolaan farmakologis.

Kebutuhan nutrisi pada penderita DM merupakan kebutuhan fisiologis yang mendasar. Pola pemenuhan nutrisi yang tidak baik menyebabkan kontrol gula darah yang tidak stabil.

\section{METODE PENELITIAN}

\section{Rancangan Penelitian}

Penelitian ini menggunakan metode kualitatif dengan pendekatan fenomenologi. Proses metodologi deskriptif mencakup 4 langkah, yakni: bracketing intuiting, analyzing dan describing (Polit \& Beck, 2012). Bracketing adalah menyimpan dan mensupresi berbagai asumsi, keyakinan dan pengetahuan yang dimiliki peneliti tentang fenomena yang akan diteliti. Langkah kedua adalah intuiting. Peneliti menggali secara mendalam sesuai apa yang disampaikan dan dirasakan partisipan tanpa adanya pengaruh dari peneliti sehingga data yang diperoleh murni berasal dari sudut 
Jurnal Care Vol .5, No2,Tahun 2017

pandang partisipan (Streubert \& Carpenter, 2003).Langkah ketiga adalah analyzing. Peneliti mengidentifikasi katakata kunci yang selanjutnya disusun untuk membentuk tema-tema. Tema-tema yang terbentuk menggambarkan persepsi pemenuhan kebutuhan nutrisi pada penderita Diabetes Mellitus.

Langkah terakhir yakni describing. Penelitian ini menjelaskan dan mendiskripsikan makna yang timbul tentang persepsi pemenuhan kebutuhan nutrisi pada penderita Diabetes Mellitus di wilayah Suruh Tani. Populasi dalam penelitian ini adalah penderita Diabetes Mellitus di wilayah Suruh Tani. Penelitian ini menggunakan metode pengambilan sampel purposive sampling. Kriteria inklusi dalam penelitian ini adalah : 1) Penderita Diabetes Mellitus Tipe 2 kurang $\geq 3$ tahun; 2) tidak memiliki gangguan kognitif (nilai MMSE $\geq 24$ );3) Tidak sedang mengalami rawat inap di rumah sakit dalam 1 bulan terakhir; Pada penelitian ini peneliti menggunakan 8 partisipan.

Penelitian dilakukan di daerah Suruh Tani kelurahan Suruh Kalang Jateng Karanganyar bulan Januari-April 2017. Instrumen dengan menggunakan lembar wawancara, catatan lapangan field note),alat perekam suara untuk mempermudah mendokumentasikan hasil wawancara yang dilakukan

\section{HASIL}

Karakteristik partisipan meliputi data demografi berupa usia, jenis kelamin, pendidikan, agama, pekerjaan, lama terdiagnosa DM dan pendidikan.

Berdasarkan demografi partisipan tersebut, diketahui bahwa paling banyak berpendidikan SMP, bekerja sebagai petani dan rata-rata terdiagnosa Diabetes Mellitus sudah 5 tahun.

\section{Tema Hasil Analisis Data Penelitian}

\section{Kepatuhan terhadap diet dapat mengontrol gula darah}

Kepatuhan merupakan suatu bentuk perilaku seseorang untuk memenuhi perintah orang lain. Dalam aspek kesehatan, kepatuhan dimaksudkan individu rela melakukan pengobatan atau terapi sesuai aturan tenaga kesehatan. Kesadaran diri, kepribadian dan pemahaman menjadi komponan penting dalam kepatuhan.

Sebagian besar partisipan mengatakan kepatuhan terhadap diet dengan 
mengontrol gula darah, hal tersebut tergambar dalam ungkapan"

"Kepatuhan makan menjadi factor utama biar sehat mbak, sebenarnya tabu, tapi kadang males untuk patub, karena bosan" P2

"Pemenuban pola makan DM kalau patuh terhadap aturan akan bagus, gulanya terkendali, gak naik-naik" P4

"Pemenuban kebutuban nutrisi DM itu yang penting patuh, gula kan man" P6

\section{Hambatan dalam pemenuhan} kebutuhan nutrisi pada penderita DM

Sub tema 1 Perasaan takut mengkonsumsi gula

Perasaan takut merupakan tanggapan emosi terhadap ancaman. Takut adalah mekanisme pertahanan hidup dasar akibat adanya stimulus. Perasaan takut dapat menghalangi upaya seseorang dalam mencapai sesuatu yang posiif dalam kehidupan. Perasaaan takut mengkonsumsi gula timbul karena anggapan bahwa mengkonsumsi gula dapat menaikkan kadar gula darah, sehingga penderita DM cenderung menghindari gula. Persepsi tersebut timbul karena sebagian besar partisipan kurang memahami tentang konsep diet pada penderita DM. Pengetahuan mereka tentang DM masih terbatas.Intepretasi ini didapatkan dari pertanyaan "Hal apa yang Anda rasakan risi sebagai penderita DM selama ini?'. Hampir seluruh partisipan menyatakan mereka takut mengkonsumsi gula dan cenderung menghindari makanan manis karena takut kadar gula akan naik. Hal ini tergambar dalam ungkapan:

"menderita kencing manis itu yang harus dibindari gula, makanan yang manis-manis mbak. Kalau kita makan manis-manis pasti kadar gula saya naik, mending saya tidak makan manis, takut mbak.". P2

" saya paling takut makan makanan yang manis-manis mbak...minum teh ya tanpa gula, buab-buahan ya yang tidak manis. Karena takut nanti tinggi gulanya.takut dirawat di RS lagi”. P5

"makanan orang kencing manis ya tidak boleh yang manis, kalau makan yang manismanis gulanya bisa naik. Takut ngedrop saya mbak" P7

\section{Sub tema 2 Diet yang sudah} ditentukan tidak sesuai selera

Selera merupakan konsep yang diasumsikan adanya pilihan-pilihan berdasarkan kesenangan, kegunaan dan pemenuhan pada situasi tertentu. Selera seseorang akan mempengaruhi 
perilaku dalam kehidupan sehari-hari.

Diet yang tidak sesuai selera menyebabkan penderita DM tidak patuh terhadap diet. Hal tersebut menyebabkan kadar gula yang tidak terkontrol dengan baik.

Berikut beberapa ungkapan partisipan yang menyatakan diet pada penderita DM tidak sesuai selera:

"Sebenarnya tabu mbak kudu makan apa, tapi gak sesuai keinginan, jadi g selera makan". P1

"gak selera mau makan mbak...gak enak..lha gak manis..hambar rasanya" P5

\section{Sub tema 3 Bosan dengan menu diet DM}

Bosan merupakan suatu bentuk emosi yang menyebabkan berkurangnya minat terhadap suatu hal. Perasaan bosan terjadi karena adanya sering datang. Sebagian besar partisipan mengatakan bosan dengan menu makanan DM, karena kurang variasi. Hal tersebut terungkap dalam pernyataan :

"Saya bosan mbak makan menu DM, lha itu-itu saja, gak bervariasi” P2

"Gimana mau patub mbak, lha bosen makanannya gak bervariasi" P4
"Bosan banget mbak...menu yang dianjurkan sama..gak enak." P7

\section{Faktor pendukung dalam} pemenuhan kebutuhan nutrisi pada penderita DM

\section{Sub tema 1 Keinginan gula darah dapat terkontrol}

Penderita DM berharap gula darah dapat terkontrol dengan baik.Motivasi tersebut muncul dari dalam diri penderita DM. Mereka mengetahui akibat gula darah yang tidak terkontrol dengan baik akan menyebabkan komplikasi yang buruk. Hal tersebut merupakan faktor pendukung utama bagi penderita DM untuk dapat patuh terhadap diet DM.

Pernyataan tersebut terdapat dalam ungkapan:

"Hal utama supaya patub terbadap menu makanan ya keinginan bisa mengontrol gula darah mbak...supaya sehat..takut.ngeri kalau tabu komplikasinya" P1

"Motivasi dalam diri untuk bisa sembuh, gula darah gake naik, itu yang mendorong mau makan sesuai aturan, hehe" P6

"Kalau ingat akibat gula darah tinggi ya takut, jadi harus patuh, makannya sesuai aturan, biar gulanya gak naik" P7 
Jurnal Care Vol .5, No2,Tahun 2017

Sub tema 2 Dukungan dari keluarga dan pelayanan kesehatan

Dukungan merupakan segala sesuatu yang mendorong seseorang untuk melakukan sesuatu. Dalam penelitia ini menunjukkan adanya dukungan keluarga dan pelayanan kesehatan berpengaruh terhadap pemenuhan diet penderita DM. Peran keluarga dalam mengingatkan, memantau dan menyediakan menu berpengaruh dalam kepatuhan diet. Pelayanan kesehatan di wilayah kelurahan memberikan pengaruh yang positif. Adanya pelayanan 24 jam bagi warga dan tes gula darah secara berkala setiap bulan sekali dapat dimanfaatkan warga. Dukungan dari keluarga dan pelayanan kesehatan mendorong kepatuhan diet DM tergambar dalam ungkapan :

"Selalu diingatkan dan dimotivasi oleh keluarga untuk manut, makan sesuai aturan, ingat suami dan anak-anak membuat semangat mbak. Meski bosan ya jadi mau makan sesuai aturan" P3

"Keluarga yang selalu mendampingi mbak, saat males, putus asa, mereka selalu menyemangati. Pengen selalu bersama mereka, itu yang membuat pengen berusaha sehat. "P5
"Keluarga dan bu bidan perawat yang ada di kelurahan selalu memotivasi supaya semangat..patuh makan biar $g$ naik gulanya. Sering memberikan informasi juga tentang DM” P6

\section{PEMBAHASAN}

\section{Kepatuhan terhadap diet dapat mengontrol gula darah}

Kepatuhan pasien terhadap prinsip gizi dan perencanaan makan merupakan salah satu kendala pada pasien diabetes mellitus. Tujuan utama penatalaksanaan pasien dengan diabetes mellitus adalah untuk mengatur gula darah dan mencegah timbulnya komplikasi akut dan kronis. Jika pasien berhasil mengatasi diabetes mellitus yang dideritanya, maka pasien tersebut akan terhindar dari hiperglikemi dan hipoglikemi (Mustofa, 2012).

Penalatalaksanaan diabetes mellitus tergantung pada ketepatan interaksi dari tiga faktor, yaitu 1) aktivitas fisik. Pasien diabetes mellitus dianjurkan latihan fisik ringan, teratur setiap hari satu atau setengah jam sesudah makan, termasuk klien yang dirawat di RS; 2) diet; 3) intervensi farmakologi dengan preparat hipoglikemis oral atau insulin. 
Jurnal Care Vol .5, No2,Tahun 2017

Hambatan dalam pemenuhan kebutuhan nutrisi pada penderita DM

Sub tema 1 Perasaan takut mengkonsumsi gula;

Banyak penderita DM dan keluarga mengira bahwa sumber kenaikan kadar gula karena pengaruh konsumsi yang manis-manis, padahal dilaporkan bahwa sebanyak 90\% penderita DM dipengaruhi oleh pola hidup yang tidak sehat terutama karena mengkonsumsi karbohidarat berlebih. Hasil wawancara menyatakan bahwa hampir seluruh partisipan menyatakan mereka takut mengkonsumsi gula dan cenderung menghindari makanan manis karena takut kadar gula akan naik.

Carbohydrate Counting adalah salah satu alternatif untuk perencanaan makan para penderita Diabetes Mellitus ini.Carbohydarate counting merupakan suatu cara alternatif untuk perencanaan makanan penderita DM ini. Carbohydrate counting merupakan suatu cara perencanaan makan penderita Diabetes Mellitus dengan terapi insulin agar memperoleh jumlah asupan makan optimal sesuai kebutuhan. (Hartono, 2012). Ketika seseorang terdiagnosis Diabetes Mellitus maka ia harus membuat perencanaan pola makan untuk menjaga kadar gula dalam darahnya. Seperti yang telah dijelaskan sebelumnya, Carbohydrate Counting merupakan cara yang tepat karena dapat memenuhi perencanaan makan penderita Diabetes Mellitus agar bisa memperoleh asupan sesuai kebutuhan dengan memperhitungkan penggunaan insulin (Mustofa dkk, 2012). Pengendalian rasa takut pasien DM dalam mengkonsumsi makanan dapat dikendalikan dengan meningkatkan pemahaman atau pengetahuan tentang pola makan. Manusia mengembangkan pengetahuannya untuk mengatasai kebutuhan kelangsungan hidupnya (Beaver, Wilson, Alam, 2011).

Sub tema 2; Diet yang sudah ditentukan tidak sesuai selera dan Sub tema 3; Bosan dengan Menu Diet DM

Diet yang bersifat membatasi akan merubah gaya hidup dan dirasakan pasien sebagai gangguan serta tidak disukai bagi banyak penderita DM karena makanan dan minuman merupakan aspek penting dalam sosialisasi, pasien sering merasa disingkirkan ketika berada bersama orang lain karena hanya ada beberapa pilihan 
makanan saja yang tersedia dan tidak sesuai selera sehingga hal ini dirasakan membosankan (Brunner, Suddarth, Smeltzer, 2008). Hasil wawancara pada penelitian ini menyatakan bahwa sebagian partisipan mengatakan dietnya tidak sesuai selera dan merasa bosan dengan menu makanan yang DM dikarenakan kurang variasi. Hal ini dapat diatasi dengan prinsip pengaturan makanan pada diebetisi yang hampir sama dengan anjuran makan untuk orang sehat dan masyarakat umum, yaitu makanan yang beragam, bergizi dan berimbang atau lebih dikenal dengan gizi seimbang maksudnya adalah sesuai dengan kebutuhan kalori dan zat gizi masingmasing individu. Hal yang sangat penting ditekankan adalah pola makan yang disiplin dalam hal jadwal makan, jenis dan jumlah makanan atau terkenal dengan istilah $3 \mathrm{~J}$.

Faktor pendukung dalam pemenuhan kebutuhan nutrisi pada penderita DM

Sub tema 1 Keinginan gula darah dapat terkontrol

Kepatuhan dapat diartikan sebagai tingkatan yang menunjukan perilaku pasien dalam mentaati atau mengikuti prosedur atau saran ahli medis. Dalam hal ini termasuk kepatuhan pasien dalam menjalankan terapi farmakologi dan pemeriksaan kadar gula darah secara rutin. Modifikasi perilaku sehat sangat diperlukan untuk pasien dengan DM diantaranya adalah tentang bagaimana cara untuk menghindari dari komplikasi lebih lanjut apabila sudah menderita diabetes. Modifikasi gaya hidup dan kontrol secara teratur atau minum obat sangat diperlukan bagi pasien diabetes. Sebuah penelitian menyatakan bahwa ketidakpatuhan penderita DM dalam pengelolaan diet dapat menyebabkan penderita mengalami tindakan amputasi (Narayan, Norris, Engelgau, 2006). Penelitian lain yang dilakukan oleh Butler (2007) menunjukkan bahwa 51 responden memiliki motivasi rendah dalam menjalankan program diet serta $56,9 \%$ responden tidak patuh dalam menjalankan program diet. Penelitian yang dilakukan Widiyaningsih \& Herlena (2013) yaitu hasil anamnesa gizi pada saat konsultasi yang ke-2 menunjukkan ternyata kepatuhan pasien dalam menjalankan dietnya hanya di lakukan pada saat pasien tinggi kadar gula darah nya. Sedangkan pasien yang sudah turun kadar gula darahnya dan kondisi 
badannya sudah merasa baik, maka pasien tidak lagi menjalankan diet.

Perilaku kesehatan individu juga dipengaruhi oleh motivasi diri individu untuk berperilaku yang sehat dan menjaga kesehatannya. Menurut Suyono (2004) dalam Gustina (2014) bahwa motivasi merupakan suatu proses psikologis yang mencerminkan interaksi antara sikap, kebutuhan, persepsi, dan keputusan yang terjadi pada diri seseorang. Kepatuhan adalah derajat dimana pasien mengikuti anjuran klinis dari dokter yang mengobatinya. Menurut Waspadji (2007) kepatuhan adalah sejauh mana perilaku pasien sesuai dengan ketentuan yang diberikan oleh profesional kesehatan.Kepatuhan sangat berkaitan erat dengan motivasi dalam diri seseorang, karena motivasi merupakan dorongan, baik dari dalam maupun dari luar diri manusia untuk menggerakkan dan mendorong sikap dan perubahan perilakunya. Motivasi ini didasarkan dari faktor internal individu yang bersifat psikologis dan sebagai akibat dari internalisasi dari informasi dan hasil pengamatan suatu objek yang melahirkan persepsi sehingga individu dapat terdorong untuk berbuat atau melakukan sesuatu. Motivasi ini yang memegang peranan penting karena motivasi berisikan perilaku, artinya dalam konteks perubahan pola makan bagi pasien DM didasarkan pada keinginan pasien untuk sembuh dan mengurangi kecatatan akibat menderita DM sehingga mereka termotivasi untuk mengikuti program diet yang dianjurkan oleh tim kesehatan.

\section{Sub tema 2 Dukungan dari keluarga dan pelayanan kesehatan}

Hasil wawancara pada penelitian ini menunjukkan bahwa sebagian besar responden menyatakan bahwa dukungan dari keluarga dan pelayanan kesehatan mendorong kepatuhan diet penderita DM. Penjelasan pada sub tema sebelumnya bahwa kepatuhan sangat berkaitan erat dengan adanya motivasi pada diri penderita DM khususnya, untuk menumbuhkan motivasi tersebut maka dibutuhkan dukungan keluarga dan akses pelayanan kesehatan yang baik. Suyono (2007), menyatakan bahwa fungsi dasar keluarga antara lain adalah fungsi efektif, yaitu fungsi internal keluarga untuk pemenuhan kebutuhan psikososial, saling mengasuh dan memberikan cinta kasih, serta saling menerima dan mendukung. Hasil penelitian ini sejalan dengan penelitian Nasrul (2011) yang menyatakan bahwa dukungan keluarga dapat 
Jurnal Care Vol .5, No2,Tahun 2017

meningkatkan kepatuhan diet DM pada pasien DM. Penelitian Syamsiah (2011) menyatakan bahwa responden yang memiliki dukungan keluarga yang baik maka memiliki kepatuhan yang baik sedangkan responden yang mendapat dukungan keluarga yang kurang baik maka tidak memiliki kepatuhan. Hasil uji statistik menunjukkan bahwa terdapat hubungan yang bermakna antara dukungan keluarga dengan kepatuhan. Kepatuhan juga sangat didukung oleh akses pelayanan kesehatan, dalam hal ini komunikasi dengan pasien adalah komponen penting dari perawatan, sehingga pemberi pelayanan kesehatan harus mempunyai waktu yang cukup untuk berbagi dengan pasien dalam diskusi tentang perilaku mereka dan motivasi untuk perawatan diri.

\section{KESIMPULAN}

Pengelolaan diet nutrisi pada pasien DM tersebut akan berhasil apabila penderita memiliki kepatuhan yang baik dalam menjalankan diet, untuk itu penderita DM membutuhkan motivasi yang baik. Motivasi akan berkembang dengan baik apabila seorang penderita DM mendapatkan dukungan keluarga dan akses pelayanan kesehatan yang baik. Responden yang memiliki dukungan keluarga yang baik maka memiliki kepatuhan yang baik sedangkan responden yang mendapat dukungan keluarga yang kurang baik maka tidak memiliki kepatuhan.

Kepatuhan memegang peranan penting karena berisikan motivasi, sedangkan motivasi sendiri memuat perilaku, artinya dalam konteks perubahan pola makan bagi pasien DM didasarkan pada keinginan pasien untuk sembuh dan mengurangi kecatatan akibat menderita DM sehingga mereka termotivasi untuk mengikuti program diet yang dianjurkan oleh tim kesehatan.

\section{Saran}

Peningkatan kepatuhan pengelolaan diet nutrisi pada penderita DM, hendaknya juga mempertimbangkan hasil analisis food recall, sehingga dapat diketahui unsurunsur gizi yang berlebihan ataupun yang kekurangan pada penderita DM.

\section{REFERENSI}

Beaver, K., Wilson, C., Alam, R., Latif, S., (2011). Patient Access To Healthcare Services And Optimisation Of SelfManagement For Ethnic Minority Populations Living With Diabetes : a 
Systematic review. University of Manchester.UK

Brunner, L.S.,Suddarth, D.S., Smeltzer, S.C., Bare, B.G. (2008). Textbook of medical surgical nursing. $9^{\text {th }}$ edition. Philadelphia: Lippincot.

Butler, H.A., (2007). Motivation: The role in diabetes self-management in olderadults. Diunduh dari http://proquest.umi.com/pqdwe b.

Gustina, Suratun, Heryati, (2014). Faktorfaktor yang berbubungan dengan Kepatuban Diet Diabetes Mellitus pada pasien DM. Kemenkes Jakarta III.

Guyton, A \& Hall, J.E. (2008). Buku Ajar Fisiologi Kedokteran. Edisi 11. EGC: Jakarta

Hartono, (2012). Basic Carbobydrat Counting bagi diabetisi RS. Panti Rapib. Yogyakarta.

Lewis L.S, Dirksen R.S, Heitkemper, Bucher, Camera. (2011). Medical Surgical Nursing: Assesment and Management of Clinical Problems, Eight Edition, (6). Elsevier Mosby: USA
PERKENI. (2011). Pengelolaan dan Pencegahan Diabetes Melitus Tipe 2 di Indonesia. Perkumpulan Endokrinologi Indonesia

Polit \& Hungler. (1999). Principles \& Methods Nursing Research. Sixth edition Philadelphia : Lippincott Williams \& Wilkins.

Smeltzer, Suzzanne C.(2001).Buku Ajar Keperawatan Medikal Bedah. .Jakarta: EGC.

Streubert, HJ \& Carpenter, DR. (2003). Qualitative Research in Nursing : Advancing the Humanistic Imperative.Third Edition. Philadelphia : Lippincott Williams \&Wilkins.

Syamsiah, N. (2011). Faktor-Faktor yang Berbubungan dengan Kepatuban Pasien CKD yang Menjalani Hemodialisa di RSPAU Dr. Esnawan Antariksa Halim Perdana Kusuma Jakarta.Tesis. Universitas Indonesia.

Waspadji,S., (2007). Penatalaksanaan Diabetes Mellitus Terpadu, Jakarta: Fakultas Kedokteran Universitas Indonesia

Widiyaningsih, Herlena, (2013). Hubungan antara pengetahuan dan sikap 
Jurnal Care Vol .5, No2,Tahun 2017

penderita DM dengan Kepatuban Diet

$D M$ di RSUD AM. Parikesit

Kalimantan Timur. 